DOI: 10.20472/IAC.2019.051.044

CHRISTA THORNHILL

Cape Peninsula University of Technology, South Africa

\title{
PERCEPTIONS OF FINAL YEAR INTERMEDIATE PHASE STUDENTS AT A SOUTH AFRICAN UNIVERSITY OF TECHNOLOGY OF THEIR READINESS TO TEACH A SECOND LANGUAGE
}

\begin{abstract}
:
The Teacher Standards in South Africa for Second Languages, other than English (DHET, 2018), expect graduate teachers to demonstrate that they understand the knowledge, skills and processes required to teach one or more of the other ten South African languages as a Second Language. According to these standards newly qualified teachers should demonstrate knowledge of home language acquisition and second language learning theories and related research findings. Teachers of Second Language should be able to recognize the reciprocal relationships between learners' languages as resources for learning and development and also have a sound knowledge of, and proficiency in, the Second Language. Graduate teachers should possess knowledge of how sounds, vocabulary and grammar of the Second Language are taught and demonstrate the ability to use a range of instructional strategies and methods to support the development of literacy in the target language. Finally, the Second Language teachers should be able to source, design and use appropriate resources. These standards are aligned with Shulman's (1987) seven major types of knowledge which should form part of any teacher's repertoire. Bachman and Palmer (1996) argue that the second language teacher should have some level of linguistic proficiency in the target language. With the emphasis on the Fourth Industrial Revolution language teachers should also know how to facilitate computer-assisted language learning (CALL). The purpose of this study is to investigate final year Intermediate Phase ( $\mathrm{gr} 4$ - gr 6 ) student teachers' perceptions of their own readiness, skills and knowledge to effectively teach Afrikaans, the second most spoken second language in the Western Cape province of South Africa. The study is a work in progress using a qualitative case study within an interpretivist paradigm. It is guided by Garrison, Anderson and Archer's Community of Inquiry as theoretical framework. The preliminary findings point to some gaps in the current curriculum and student teachers' knowledge. There is also a need to improve the student teachers' proficiency in the target language.
\end{abstract}

\section{Keywords:}

Second Language Teaching, Teacher Knowledge, Teacher Standards 